\title{
THE COMPATIBILITY OF INTERNATIONAL LAW AND ISLAMIC LAW (SHARI'A): A CASE STUDY OF INDONESIA
}

\author{
Nuriyeni Kartika Bintarsari ${ }^{1}$
}

\begin{abstract}
Abstrak
Tulisan ini menganalisa apakah ada persamaan antara hukum internasional yang bersumber dari Barat dan hukum Islam (Syariah) yang banyak diterapkan di negara-negara dengan mayoritas penduduk beragama Islam antara lain Negara-negara di Timur Tengah, sebagian Afrika (Negaranegara Magribi), dan sebagian negara di Asia Tenggara antara lain Indonesia, Malaysia dan Brunei Darussalam. Hukum internasional dan Hukum Islam (Shari'a) memiliki persamaan mendasar dalam hal hak asasi manusia terutama jika dikaitkan dengan perlakuan yang sama apapun jenis kelaminnya. Tulisan ini mencoba menganalisa persamaan antara hukum internasional dan hukum Islam terkait hak-hak perempuan dalam pernikahan. Propinsi Aceh, Propinsi Sulawesi Selatan dan Propinsi Jawa Barat adalah 3 (tiga) propinsi di Indonesia yang menjadi studi kasus dari tulisan ini.
\end{abstract}

Kata-kata kunci: Indonesia, Hukum Internasional, Hukum Islam (Syariah), Hak-hak perempuan

\section{Introduction}

International law is imbued with western-led values, highly concerned on human rights and humanism issues. International law principles are regulating the international actors interaction. The world witnesses the rising notion of the Responsibility to Protect (R2P) as recognition on how important is a human life. Human life is sacred, that not even state where the person resides can cause any harm toward him or her. International law in this sense is seen as the way international politics actors such as: states, multinational corporations (MNCs), nongovernmental organizations (NGOs), prominent individuals, and others must conduct their activities in the civilized international community. On the other hand, there is another set of law formulation that also widely applied in some region of the world. The Islamic law or Shari'a is widely applied in countries in the Gulf region, Northwest part of Africa (Maghribi states) and in the Southeast Asia region, such as in Indonesia, Malaysia and Brunei Darussalam.

The purpose of this paper is to analyze and examine whether there is a compatibility of international law and shari'a. If so, why and how the international law and Shari'a will be compatible? The paper will argue that the

\footnotetext{
${ }^{1}$ Staf pengajar Program Studi Hubungan Internasional, FISIP Universitas Jenderal Soedirman. Kandidat PhD di Rutdgers University.
} 
international law and shari'a law is compatible, especially in the recognition of certain basic human rights, such as in the equality between all human beings regardless of their gender. The examination is on the area of how Islamic law affects women's rights in Indonesia, in this case rights in marital life for women in Indonesia. This paper will analyze whether Shari'a is compatible with international law in terms of women's rights. The analysis is based on the implementation of sharia in Indonesia, in which I will elaborate the case study of Shari'a implementation in the Aceh province, South Sulawesi province and West Java province.

In the first section, the paper will analyze theoretical ground on the explanation of International law and Islamic law. The intersection and compatibility of International Law and Islamic Law will be the highlight of this section. The second section will discuss the condition of Indonesia, as the most populous Muslim in the world. Indonesia was chosen because it is the largest Moslem country in the world that also upholds democracy values, so it represents the intersection of the International law and Islamic law. The recognition of women rights in Indonesia is the main concern in this essay; elaboration on the marriage law and its impact on women's welfare in those three provinces will be analyzed. The last section will be a conclusion

\section{International law and Islamic Law}

The International Law discussed throughout this paper is defined as "International law consists of the rules and principles of general application dealing with the conduct of states and of international organizations in their international relations with one another and with private individuals, minority groups and transnational companies" (Beckman \& Butte at: http:// www.ilsa.org/jessup/intlawintro.pdf). Based on this definition, one can comprehend that international law focuses on the general application of its rules and principles in the international sphere. International law is seen as the law that arranges all legal affairs internationally. International actors described in the definition above are the subjects of the international law. On the other hand, there is an Islamic law that also perceives having the same legitimate right to arrange all legal matters, especially in the Islamic countries.

One of the leading professor in the Islamic Jurisprudence studies, Abdullahi Ahmed An-Na'im, offers a definition of Shari'a or Islamic Law as "the whole duty of Mankind; it is moral and pastoral theology and ethics, high spiritual aspiration, and detailed ritualistic and formal observance"(An-Na'im, 2010, p.43). The definition refers to a set of moral standard and norms guided by certain values in spiritual sense, which every human beings must follow through. An-Na'im further explained that the sources of Shari'a are The Qur'an and Sunna/Sunnah. The Qur'an or Al Qur'an is the holy book of Muslim which AnNa'im explained as "the Prophet Muhammad 
received the literal and final word of God, the Qur'an, between 610 and 632 C.E" (AnNa'im, 2010, p.43). The Qur' an is written in Arabic language and its originality is preserved throughout centuries of teachings and learning, any change or addendum in Al Qur'an is strictly prohibited. To help non Arab Muslims worldwide, translation of $\mathrm{Al}$ Qur'an is available in various languages based on the authentic texts.

Sunna or Sunnah also sources back from the same period of Al Qur'an formulation, in which "the Prophet is believed to have explained and elaborated on the principles of divine revelation through verbal statements, his own actions, and approval of the actions of his followers" (An-Na'im, 2010, p.43). Sunnah refers to a collection of works on how the Prophet Muhammad in his sayings and his behaviors pertaining public and private affairs. Muslims are expected to emulate the way the Prophet Muhammad behaves in their daily activities. Kamali indicated the necessity of all Muslims to return to the source of all legal principles in sura al-Nisa (4:58-59): 'O you believers! Obey God and obey the Messenger and those of you who are in charge of affairs. If you have a dispute concerning any matter, refer it to God and to the Messenger'. (Kamali, 2011, p.11) The verse is a clear proof that all matters concerning Muslims life must be conducted in reference to God (Allah) and to the Messenger (Prophet Muhammad). This topic is interesting because of the growing concern on the application of
Islamic law as perceives not to be in compliance with the international law.

International law and Islamic law are not necessarily stand between opposite site in practices. Take an example in matter of violence. An-Naim mentioned that "from a formal point of view, it can be said that Islamic law prohibits all violence except in cases of official punishment for crime, strict private self -defense, or formally declared legitimate war as regulated by law" (An Na'im, 2010, p.35). Violence as an official punishment and as an act of self-defense can be categorized as a necessary to protect individual or society from further harm. Harm here refers to the criminal and outlaws conducts by those who deserves to be punished with violence. However, excessive violence and abuse of power are strictly forbidden in settling disputes. International law also forbids the use of excessive forces since one of its goals is to maintain peace.

In the context of Islamic law, Kamali explained that one need to understand the Usul al-fiqh as it 'concerned with the sources of Islamic law, their order of priority, and the methods by which legal rules may be deduced from the source materials of the shari'ah' (An Na'im, 2011, p.11). Usul al-fiqh itself refers to the methodology to gain specific knowledge on forming law based on the sources of Shari'a, Al Qur'an and Sunnah.

There are other Islamic scholar such as Kamaruzzaman Bustamam-Ahmad that goes into detailed explanation on the difference between fiqh, shari'a and qannun, where those 
three terminologies refers to the Islamic law with different methods of understanding and practice (Kamaruzzaman Bustamam-Ahmad, 2007). For the purpose of this paper, the Islamic law discussed here refers to the Shari'a. The implementation of Shari'a itself cannot be separated from other factors such as: history, sociology, cultural values and socioeconomic in a specific nation state. An Naim explained, "Other aspects of Islamic consciousness, such as perceptions and experiences of piety and spirituality, as well as socioeconomic and political factors, are always integral to an understanding of Muslim beliefs and behavior" ( An-Na'im, 2011, p.144). The statement implies that generalization in Shari'a implementation's research is hazardous; it can lead to over simplification on the research results.

The application of International law needs voluntary compliance of international actor such as nation states to good relations toward each other. One of the prominent international actor actively involves in the implementation of international law is the United Nations (UN). The United Nations General Assembly Resolution 2625 described 'the principles governing relations between states' (Beckman \& Butte at: http:// www.ilsa.org/jessup/intlawintro.pdf):

1) States shall refrain in their international relations from the threat or use of force against the territorial integrity or political independence of any state, or in any other manner inconsistent with the purpose of the United Nations.

2) Pacific settlement of disputes.

3) Non-intervention in matters within the domestic jurisdiction of any state, in accordance with the Charter.

4) Co-operation with one another in accordance with the Charter.

5) Equal-rights and self-determination of peoples.

6) Sovereign equality of states

7) States shall fulfill in good faith the obligations assumed by them in accordance with the Charter

The philosophy of the above principles is to enable the UN to attain its primary goal as stated in Chapter 1 Article 1 of the UN Charter. (Charter of the United Nations and Statute of the International Court of Justice, 1945, Chapter 1 Article 1)

There are four main purposes and one of them intent: "to achieve international cooperation in solving international problems of an economic, social, cultural, or humanitarian character, and in promoting and encouraging respect for human rights and for fundamental freedoms for all without distinction as to race, sex, language, or religion" (Charter of the United Nations and Statute of the International Court of Justice, 1945, Chapter 1 ) Article 1 (3)). This statement of purpose is a strong commitment from the international actors to engage in the full achievement of human rights. 
In Shari'a, the purview of such an acknowledgement of human rights can be read in Kamali's book as 'thirty ayat speak of justice, equality, evidence, consultation, and the rights and obligations of citizens. About twenty-five ayat relate to international relations regulating relations between Muslims and non-Muslims'(Kamali, 2011, p.27). Ayat here refers to verses in the Qur'an. In cases when The Qur'an speaks about equality in term of economic justice, it usually refers to Shadaqah (charity) or Zakah (a compulsory tax given to those in need after certain accumulation of wealth). Charity and tax are also known in the Western states as way to spread wealth and welfare among people. The Qur'an also rigidly regulates the relations between men and women in marriage. The Shari'a offers abundant sources pertaining men and women relations in marriage, divorce, family disputes, inheritance, and in child rearing.

The cosmopolitan spirit in human rights attainment makes it a good subject in the international law. Slaughter pointed the needs of a global community of human rights law (Slaughter, 2004). Furthermore, Slaughter explained that in protecting the human rights from the abuse of higher authority, including states, there must be courts "to determine the appropriate level of protection in light of a complex matrix of historical, cultural, and political needs and expectations" (Slaughter, 2011, p.79). Perceptions and legal notion of justice are universal everywhere in the world.
Nevertheless, in a matter of how this global justice is being exerts and perceives depend on myriad factors involving sociological, historical, cultural and socio economic condition of each nation states. The global courts describes by Slaughter also involves the availability of global judges and prosecutors to work on international law cases. Institutions that represent the embodiment of global courts are: The International Court of Justice (ICJ), which is the UN's highest Judicial Body; and The International Criminal Court (ICC), established in 2003 (International Criminal Tribunals and Special Courts. Available at: https://www.globalpolicy.org/internationaljustice/international-criminal-tribunals-andspecial-courts.html). Critics and resentments are always appear whenever some cases are being held in this international courts, however further analyses on this subject are not the main topic in this paper.

\section{Women rights in Indonesia: In Marital life and Public affairs}

Indonesia is home to approximately 205 million Muslims, according to the 2010 Pew Forum Demographic Study (Muslim Population of Indonesia. Available at: http:// www.pewforum.org/2010/11/04/muslimpopulation-of-indonesia/). The number shows that $88 \%$ of Indonesian population is Muslims. The data shows that Muslims is the majority population in Indonesia, followed by Christians, Catholics, Hindus, Buddhists and Confusianists. Bowen wrote a chapter entitles 'Contours of Shari'a in Indonesia' that 
explains 'in more than one-third of Indonesia's provinces, at least one region or city has enacted regulations intended to introduce Shari'a (or the spirit of Shari'a) into local public life' (Bowen, 2013, p.149). This is mostly happens after the end of the New Order era in late 1998, which marked the beginning of the Reformation era. The reformation era is the era of democratization, which is considered very successful compared to some Islamic states such as Egypt, Tunisia and Iran (Bowen, 2013, p.8-9). In Egypt, the Arab spring revolution did not turn out as expected, which left the democracy practice at bay. Kunkler and Stepan (Kunkler \& Stepan, 2013, p.3) wrote that "Indonesia, the world's most populous Muslim-majority country, began a transition to democracy with the overthrow of Suharto in 1998 and now strikes most observers as a democratization miracle". The perception of Indonesia as a democratization miracle did shape a lot of changes in the social, economic and political life. Admittedly, gender relations become one of the results.

In Indonesia, the successful transition to democracy does affect the way women exert their rights. Women are gaining bigger roles in the public sphere, especially after the political parties adopted 30\% quota for female candidates, starting from 2004 general election till recent general election, in 2014. During the New Order Regime under Soeharto's presidency (1967-1998), there were restrictions in the way women were able to participate in the public sphere. The ministerial positions reserved for females were limited, as in the Ministry for Social affairs and Ministry of Women affairs, thus filled in the position stereotyping female natural roles.

In the matter of public or political affairs, Indonesia already appointed one female president, Megawati Sukarnoputri, who was in office on July 2001-October 2004 (Kunkler \& Stepan, 2013, p.115). Megawati tackled the issues of terrorism and internal conflicts with great success. The evidence is as shown by Malino accord to settle the communal dispute in Poso, located in Central Sulawesi province (Kunkler \& Stepan, 2013, p.116). Megawati never downplayed the issue for women's rights during her times in the presidential office; she continued the national program to eliminate all forms of discrimination against women. Indonesia had ratified the Convention on the Elimination of All Forms of Discrimination against Women (CEDAW) in 1984 and the Ministry of The Role of Women was assigned as the national task force to implement the convention (Indonesia. Available at http:// asiapacific.unwomen.org/countries/ indonesia\#sthash.V9ZmfKLp.dpuf). In the era of reformation, there are no obstacles for women to hold a high rank position in the public offices. The political parties are agreed to impose a $30 \%$ quota for female representatives to be elected in each election period. Despite all efforts above, there is a growing concern about the restriction for women to participate in the public affairs, 
especially in the Aceh and South Sulawesi provinces. Both provinces were implemented the Shari'a (Kunkler \& Stepan, 2013).

The government had signed the Convention on The Elimination of All Forms of Discrimination against Women (CEDAW) on July 291980 and ratified it on July 241984 (CEDAW Country Report- Indonesia. Available at: http://daccess-dds-ny.un.org/doc/ UNDOC/GEN/N97/051/89/IMG/N9705189. pdf?OpenElement). The Convention ratified with Indonesian Act No.7/1984, and reservation was made in article 29 (1). The Indonesia's country report explained, "It was considered inappropriate for the International Court of Justice to interfere with the domestic problems in Indonesia". (CEDAW Country Report- Indonesia. p.7) It was occurred during the period when the International Court of Justice was a novel institution in the United Nations (UN). Indonesia was not comfortable enough to allow the representation of Western judicial system to interfere with its domestic affairs, this attitude supported by long history of colonization by western powers.

The CEDAW has served as a national guidance on women empowerment and the New Order regime implemented it in the fiveyear development plans since the ratification date. The Five-year development plan of Indonesia is known as Rencana Pembangunan Lima Tahun (Repelita). (CEDAW Country Report- Indonesia. p.10) The Indonesian Ministry of The Role of Women was acted as an institution to host the CEDAW regulation.
Today, the Ministry of The Role of Women has changedinto The Indonesian Ministry of Women Empowerment and Children Protection. CEDAW is the international law instrument to achieve the attainment of women and children rights. In the fourth International Conference on Women in Beijing, held in 1995, 189 government representations and CEDAW member delegations had agreed on the Bejing Declaration and Platform of Action. The platform consists of twelve critical areas of concern: a) Women and the environment; b) Women in power and decision-making; c) The girl child; d) Women and the economy; e) Women and poverty; f) Violence against women; g) Human rights of women; h) Education and training of women; i) Institutional mechanisms for the advancement of women; j) Women and health; k) Women and the media; 1) Women and armed conflict (The Beijing Platform for Action: inspiration then and now. Available at: http:// beijing20.unwomen.org/en/ about\#sthash.slmuthlC.dpuf).

Those twelve critical areas are essential in addressing gender issues worldwide. The New Order regime had formulated a law on marriage in 1974, which regulates marriages, divorces and husband's rights to get a divorce without his wife's consent or talaq (UndangUndang Republik Indonesia Tahun 1974 Tentang Perkawinan. Available at: http:// www.hukumonline.com/pusatdata/ detail/26834/node/18/uu-no-1-tahun-1974perkawinan. See also Katz \& Katz, 1975. p. 
653-681)

The law on Marriage no. 1 (1974) has been redrafted several times to accommodate the resentment on the absolute right of a husband to divorce his wife. The 1991 compilation 'require that the husband show grounds for divorce in court and stipulate that the divorce occurs if and only if the judge permits the husband to pronounce the talaq' (Bowen in Kunkler \& Stepan, 2013, p.31). The court that arrange about this matter is the Islamic court (pengadilan agama). The new arrangement proof to be fair and beneficial for the couple, often times the marital disputes can be mediated through the same court. There are some reviews for the 1974 law of marriage, such as in the application of polygamy and inter-religious marriages. (Bedner \& Van Huis, 2010, p.175191) Polygamy in Islamic law is legal. There is a leeway for husband to remarry and accumulate four wives at the same time. The arrangement is possible as long as he can act justly toward all of his wives. However, the research conducted by Bedner and Van Huis found out that polygamy was the primary reason for divorce cases in West Java province. Bedner and Van Huis were mesmerized by the fact that " 42 of the 120 interviewed women (35\%) stated that polygamy of their husband was the main reason for divorce" (Bedner \& Van Huis, 2010, p.184). In the 1974 State Marriage Law, polygamy is legal after the Islamic court obtained permission for the husband to conduct that. Permission is possible after the husband secure his wife's consent on that matter. Research found out that there is not the usual case. Men usually conducted his second, third or fourth marriage without his spouse's permission. This reckless act mostly affect new wives and children born in the latter union, as the children will not be recognized as legitimate and could not claims inheritance from his father's family. The problem has been addressed at the national level; government now imposed stricter regulation for husbands to remarry, especially if he works as a civil servant.

The South Sulawesi was capturing the national attention because "it was one of the first provinces to capture international attention for local efforts to promote Shari'abased law" (Bowen in Kunkler \& Stepan, 2013, p.158). The reason behind this act was growing concerns on moral degradation of its people and the failure of government to keep public order (Bowen in Kunkler \& Stepan, 2013, p.158). Bowen noted that The Committee for the Preparation and Creation of Islamic Shari'a carries out the enactment of Shari'a in South Sulawesi. In local language it was known as The Komite Persiapan dan Penegakan Syariat Islam (KPPSI).

In one of South Sulawesi's county, Bulukumba; the KPPSI started the implementation of Shari'a in adding the Arabic script on street signs. In the matter of marriage law, Bulukumba's authorities ensure that the groom and bride-to be are able to recite the 
Qur'an before initial marital vows or akad nikah. In cases when the couples could not demonstrate the Qur'an recitation, the wedding will still be held, but their family will have to endure the humiliation caused by that incident. Students and civil servants also become subjects of this new rule, in which they must mastered the verse of Al Fatihah, the first verse in the Qur'an and very crucial because every Muslims have to recite it daily in their five times prayer (Sholat).

Tax and charity in Islamic law (Zakah and Shadaqah) are also collected and the Bulukumba's government claimed that those economic contributions are important for justice and equality among people. The local government emphasized on the Qur'an teachings and comprehension among the Bulukumba's residents. During the essay's research, formal restrictions that banned women from participation in the public sphere were nowhere to be found. The implication from this fact is that women are allowed to participate in public offices in Bulukumba, where Shari'a is enacted.

In the Aceh province, the Shari'a enactment has run smoothly compared to other provinces in Indonesia. Bowen examined that "Aceh long has constructed its special identity around its Islamic history and culture, and it now, alone among Indonesian provinces, has the legal right to reconstruct its legal system on the basis of sharia" (Bowen in Kunkler \& Stepan, 2013, p.161). The statement found its validity in the historical context. Since the era of the Dutch colonization, the region of Aceh had declared itself to be the veranda of Mecca (Serambi Mekah). It is widely known that Mecca is the center of Islamic teaching and by declaring itself as the veranda of Mecca; Aceh has claimed its strong ties with Islamic values.

The Aceh province enacted Shari'a as early as 1999, and the Acehnese Parliament has formulated an Islamic law called qanun (Bowen in Kunkler \& Stepan, 2013, p.161). The implementation of qanun is ubiquitous in Aceh's public and private matter. Women in Aceh are expected to dress modestly, wearing head covers (jilbab) and men are to attend the Friday prayer promptly. Alcohol, gambling, adultery, and theft are considered as heavy violation of Islamic law. The Aceh authoritative regulate matters concerning marriage law, commercial law and criminal law. There were some cases where the police raided the female motorcycle riders on the street because they were wearing tight pants and asked them to pulled over and changed into skirts. Those events were wreak havoc in the national news headlines, as people accused that Aceh police officers being sexist and targeted women in the Shari'a implementation (Komnas perempuan kecam aturan tentang posisi duduk perempuan Aceh. Available at:http://www.voaindonesia.com/content/ komnas-perempuan-kecam-aturan-tentangposisi-duduk-perempuan-aceh/1577533.html). The Indonesian Committee on Women Affairs (Komnas Perempuan) has coordinated with 
the Aceh government concerning this issue and settle the controversy.

\section{Conclusion}

The compatibility of International law and Islamic law (Shari'a) is palpable. The recognition on human rights, including women rights, is present both in the International Law and Shari'a principles. Indonesia as the most populous Muslim country in the world shows that in the reformation era, there is more and more opportunity for women to be actively participating in public affairs. There are three provinces set as an example on how Shari'a law is implemented, mainly in the Aceh Province, the South Sulawesi Province (Bulukumba Region) and West Java Province. In those three provinces, researches showed that in the matter of marriage and public affairs, the Shari'a serves to protect the interest of women and children, albeit some perversion from its original intentions. The marital status of women and men is important in those three provinces, because it correlates with fulfillment of women and children rights, especially their economy and social rights. There are no specific records on restrictions imposing on women in the public sphere. Women and men are having equal opportunity to participate in the public offices in Indonesia. The case studies prove that the international law and Shari'a law serve as guidance for the attainment of human rights. 


\section{References}

\section{Books and Articles}

An Na'im. AA. Muslims and Global Justice. Philadelphia. University of Pennsylvania Press. 2010.

An Na'im, Abd Allah Ahmad. "Islamic Foundations of Religious Human Rights". Muslims and Global Justice. 2011.Pp.140-160

Bedner, Adriaan. And Van Huis, Stijn. "Plurality of Marriage Law and Marriage Registration for Muslims in Indonesia: a Plea for Pragmatism". Utrecht Law Review. Vol. 6, Issue 2 (June). 2010

Bustaman-Ahmad, kamaruzzaman. "The Application of Islamic Law in Indonesia: The Case Study of Aceh. Journal of Indonesian Islam. Vol.01. No. 01. June 2007. pp. 135-180.

Charter of the United Nations and Statute of the International Court of Justice. San Francisco. 1945

Kamali, M.Hashim. Principles of Islamic Jurisprudence. Cambridge. The Islamic Texts Society. 2011.

Kunkler, Mirjam. And Stepan, Alfred. Democracy \& Islam in Indonesia. New York. Columbia University Press. 2013.

Katz, June S. and Katz, Ronald S. "The New Indonesian Marriage Law: A Mirror of Indonesia's Political, Cultural, and Legal Systems". The American Journal of Comparative Law. Vol. 23, No. 4. Autumn. 1975

Slaughter, Anne-Marie. A New World Order. Princeton. Princeton University Press. 2004

\section{Electronic Sources}

Beckman, Robert \& Butte, Dagmar. Introduction to International Law. Available at: $\quad \underline{\text { http:// }}$ www.ilsa.org/jessup/intlawintro.pdf

CEDAW Country Report- Indonesia. Available at: http://daccess-dds ny.un.org/doc/UNDOC/ GEN/N97/051/89/IMG/N9705189.pdf?OpenElement 
International Criminal Tribunals and Special Courts. Available at: https://www.globalpolicy.org/ international-justice/international-criminal tribunals-and-special-courts.html

Komnas perempuan kecam aturan tentang posisi duduk perempuan Aceh. Available at:http:// www.voaindonesia.com/content/komnas-perempuan-kecam-aturan tentang-posisi-dudukperempuan-aceh/1577533.html

Muslim Population of Indonesia. Available at: $\quad$ http://www.pewforum.org/2010/11/04/muslim -population-of-indonesia/

The Beijing Platform for Action: inspiration then and now. Available at: http:// beijing20.unwomen.org/en/about\#sthash.slmuthlC.dpuf

Undang-Undang Republik Indonesia Tahun 1974 Tentang Perkawinan. Available at: $\quad$ http:// www.hukumonline.com/pusatdata/detail/26834/node/18/uu-no-1-tahun 1974-perkawinan 